\title{
Aydınlanma Perspektifinden Doğu'nun Modernleşme Sorunu ve Çağdaşlaşma
}

\author{
DOI: 10.26466/opus.765187
}

*

\author{
Ergin Ulusoy * \\ * Dr. Öğr. Üyesi, Nuh Naci Yazgan Üniversitesi \\ E-Posta: eulusoy@nny.edu.tr \\ ORCID: $\quad \underline{0000-0002-0145-7729}$
}

\section{Öz}

Çalışma, Batı ile Doğu arasında yaşanan ayrışmanın temellerini ve bu ayrışmanın modernizm ekseninde bir kopuşa dönüşmesini konu edinmiştir. Bu bağlamda çalışmanın ana hipotezi modernizmin Antik Yunan mirasına dayanan bir zihin atlası üzerinde inşa edildiği ve bu bağlamda Batı ile Doğu arasında birbirlerinden kopmalarına neden olan çok köklü bir farklılık bulunduğudur. Bu farklılık Aydınlanma ile birlikte doruk noktasına çıkmış ve Batı'nın episteme, Doğu'nun doxa'yı sahiplendiği bir dikotomiye evrilmiştir. Çalışma, Doğu'nun modernleşmesinin imkansızlı̆̆ın savunmakta ve konuyu bir epistemoloji-ontoloji ikiliği içerisinde kavramaktadır. Batı kendini Aydınlanmayla birlikte bilen olarak konumlandırmış, kendisi karşısındaki her şeyi bilinen olarak ele almıştır. Bu, Batı'nın karşılaştı̆̆ diğerlerini ötekileştirmesine hatta araştırmalarının konusu olarak nesneleştirmesine ve didiklemesine yol açmıştır. Doğu bu ikilemin sonuçlarıyla en ağır biçimde yüzleşmiş ve sonunda başına gelenleri ilerigeri ikiliği çerçevesinde okuyarak gelişmek, değişmek, Batılllaşmak ve Batı'ya yetişmek istemiştir. Bu yargı, Batı elitinden çıkan modernizmin Doğu'nun içine işlediğ̀i anlamına gelir. Zira gelişmek istemek, geriliğini kabul etmek; kendini Batı'nın gözünden görmek demektir. Çalışma bu izlek doğrultusunda Doğu modernleşmesinin imkansızlı̆̆ın tartışmakta ve bu imkansızlık nedeniyle çă̆daşlaşmaya ve kalkınmacılığa evrildĭ̆ini iddia etmektedir. Çalışmamızda Antik Yunan, Aydınlanma ve modernizm ekseninde Batı, modernizm-geleneksellik çatışkısı ve Doğu'nun modernizmle olan sorunlu ilişkisi irdelenmiştir. Çalışmanın hazırlanmasında basılı ve elektronik kaynakların değerlendirilmesi suretiyle literatür taraması yapılmış ve determinist, epistemolojik bir tutum izlek edinilmiştir. Çalışma, post-modernist bir uzlaştırma çabası değil, Doğu modernleşmesinin imkansızlı̆̆ıı ve bu imkanszılık nedeniyle çă̆daşlamşmaya ve kalkınmacılığa evrildiğini iddia eden bir açıklama gayretidir.

Anahtar Kelimeler: $\quad$ Modernizm, Doğu-Batı, Aydınlanma, Çağdaşlama, Doğu modernleşmesi 


\title{
Modernization Problem And Contemporation Of East From Perspective Of Enlightenment
}

\begin{abstract}
Our study focuses on the fundamentals of the separation between the West and the East and the transformation of this separation into a break in the axis of modernism. In this context, the main hypothesis of the study is that modernism was built on an atlas of mind based on the Ancient Greek heritage, and in this context, there was a radical difference between the West and the East that caused them to break apart. This difference peaked with Enlightenment and evolved into a dichotomy where the West owned the episteme and the East owned the doxa. The study advocates the impossibility of the modernization of the East and grasps the subject in an epistemology-ontology duality. The West described itself as knowing with Enlightenment, and considered everything against it as known. This has led the West to marginalize others he has encountered, even to objectify and peck at the subject of his research. The East faced the most severe consequences of this dilemma and wanted to develop, change, Westernize and catch up with the West by reading what happened at the end, back and forth. This judgment means that modernism from the West is embedded in the East. Because to want to develop, to accept his backwardness; means to see yourself through the eyes of the West. During the preparation of the study, the literature was scanned by evaluating the printed and electronic resources and a deterministic and epistemological attitude was acquired. The work is not a post-modernist reconciliation effort, but an explanation effort that claims the impossibility of Eastern modernization and its evolution into modernization and developmentalism due to this impossibility.
\end{abstract}

Keywords: Modernizm, East-West, Enlightment, Become contemporary, Modernization of the East 


\section{Giriş}

Modernizm her şeyiyle başka bir evrendir. Batı'nın kendine özgün toplumsal süreçlerinin içinde biçimlenmiş bir zihin atlasıdır. Dolayısıyla modernizmin paradigmasını oluşturan her bir unsur Batı'ya özgü ve Batı ile ilgili olmak durumundadır. Çalışmanın temel tezi, bu noktada, Batı'ın Antik Yunan'da temelleri atılmış olan epistemeye yönlendiği; şüphecilik, akılcılık, tümevarım ve ölçümleme (sınıflandırma ve tanımlama da bu kapsamdadır) yoluyla evrensel ilkeler ve yasaların bilgisini açıklayıcı bir çerçevede ilerlediği buna karşın Doğu'nun ise doxa'yı sahiplendiği; tümdengelimci bir çizgide kaderci, gelenekçi, anlamlandırma odaklı bir düzen izlediğidir. Bu manada yaşanan ayrışmanın Batı ile Doğu arasında kapanması mümkün görünmeyen bir fark ortaya çıkardığı savunulmaktadır. Söz konusu ayrışma Doğu'nun modernleşememesinin ve Batı ile geliştirdiği çatışmalı ilişkinin nedenini oluşturmaktadır. Episteme ile doxa ayrışması, bilen-bilinen ikiliğini kemikleştirerek etkenedilgen, aktif-pasif ikiliklerine yaptığı vurguyla iki coğrafyayı iki ayrı medeniyet olarak kökten ve sonsuza dek ayırmışır.

Modernleşme konusunda Doğu ile Batı çatışkısı ve Doğu'nun gelişme gayreti genellikle kültürün de dahil edildiği bir olgular düzlemi üzerinden tartışılmaktadır. Oysa ayrışmanın ve çatışmanın köklerine inilmeden, gerçek nedenler orataya konmadan Doğu ile Batı arasında modernizm ekseninde yaşanan kesin kopuş anlaşılamaz. Bu çalışma söz konusu tartısmayı daha temel bir düzeye indirerek fakat özellikle kelimelere vurgu yapmadan bir epistemoloji-ontoloji tartışması olarak ele almış, teorik bir düzlemde epistemedoxa ayrımının, tümevarım-tümdengelim farkının sonuçlarını modernizmgeleneksellik ekseninde açımlamış; bugünkü Doğu-Batı çatışkısını ve Doğu'nun modernizm konusundaki sıkıntılarını irdelemiştir.

Antik Yunan'da felsefenin ortaya çıkışı karşısında Doğu'nun dinlerin beşiği olması tesadüf değildir. Tek tanrı inancının Doğu coğrafyalarından çıması, Batı́nın bir noktadan sonra Hristiyanlığı dahi paganlaştırarak özerkleştirmesi esasen refleksivitenin önemini göstermektedir. Refleksivite insanın ve toplumun, tanrı(ların) varlığından bağımsız biçimde, kendi varlığı ve var oluşu üzerine düşünerek tarihsel olarak kendi üzerine kapanmasının adıdır. Doğu bu noktada içe dönük, mana arayışında bir kültür geliştirmiştir. Batı'nın Aydınlanma ile aştığı ereksellik Doğu için olmazsa olmazdır ve onun kaderciliğinin ve statik, çelişkilerle dolu toplumsal yaşamının ana nedenidir. 
Modernizm ve modernleşme çabası bu farklılıklar üzerine oturan bir çatışma alanı yaratır. Dolayısıyla Doğu-Batı dikotomisini anlamak için olgular kadar hatta belki biraz daha fazla temel nedenlere yönelmek; bu ayrışmayı episteme-doxa ayrımı üzerinden okuyabilmek gerekir.

Bu kapsamda çalışma üç ana başlıktan oluşturulmuştur. İlk bölüm Antik Yunan mirası olarak adlandırılabilecek olan refleksivite kavramını önemine ve bu bağlamda Aydınlanma'ya ve modernizme değinmiş, ikinci bölüm modernizm karşısında gelenekselliğin ontolojisini açımlamış, üçüncü bölüm ise Doğu'yu Aydınlanmacı bir perspektifte ele almış ve onun modernizmle olan şiddetli ilişkisini Batı ile ilgisi çerçevesinde incelemiştir. Son dönemde postmodern ataklar hızını kaybetmiş olsa da modernizmin artık aşıldığının anlaşılmaya başlanması ile Doğu'nun modernleşme sorunun episteme-doxa ayrımı eksenin idrak edilebilmesi daha da önemli hale gelmiştir. Bu nedenle çalışma post-human (insan-ötesi) olarak adlandırılan yeni dönemin kıyısında dünyanın daha huzurlu, güvenli bir yer olabilmesi için Batı ile Doğu arasındaki farklılığın kavranması gerektiği inancıyla ortaya konmuştur. Çalışmanın niyeti bugün Doğu-Batı arasındaki ayrışma ve çatışmaların iyi tahlil edilmesiyle daha iyi gelecek kurulmasına bilimsel bir katkı sağlamaktır.

"Bilmek, nedenlerle bilmektir."

Aristoteles

\section{Refleksivite (Düşünümsellik)'nin “Aydınlığında” Modernizm}

Modernizm her halükârda geleneksel olandan bir kopuştur. "Gelenek, bir topluluğun kendinden önceki kuşaklardan devraldığı ve çeşitli aktarım yöntemleri kullanarak daha sonraki kuşaklara ulaştırdığı her türlü maddi, manevi kurum ve uygulamalar biçimi olmakla beraber bir önceki duruma ait olanın bir sonraki durum için de yenilenmesidir" (Yılmaz, 2005, s.41). Bu doğrultuda modernizm, toplumsal yaşamı meydana getiren insan-doğa ve insan-insan ilişkilerindeki durağanlığın tecrübe fetişizmi, patriarşi ve gerontokrasiye yol açtığı; geçimlik iktisadın kültür ve politikayı kuşatarak insanlığın ilerleyişini yavaşlattığı hatta yer yer durdurduğu uzun bir dönemin devrimci bir aksiyomla sona erdirilmesidir. "Modernlik fikri, toplumun merkezindeki Tanrı'nın yerine bilimi koyarak, dinsel inançlara - en iyi olasılıkla ancak özel 
yaşam dâhilinde bir yer bırakır. Modernlikle en güçlü bir biçimde özdeşleştiği anda Batı düşüncesinin özelliği, akılcıllğa tanınan temel rolden daha geniş bir fikre, akılcı bir toplum fikrine geçmeyi istemiş olmasında yatar; ve o akılcı toplum' da akıl yalnızca bilimsel ve teknik etkinliği yönetmekle kalmaz, insanların yönetimini ve nesnelerin yönetimini de elinde tutar" (Touraine, 2002, s.22-34). Modernizm insanın aklı merkeze alması, doğa yasalarını keşfetmesi ile birlikte inanç üzerinden biçimlendirilmiş her türlü sahtecilikten ve dinsel yanılsamadan sonsuza dek kurtulmasıdır. Modernizm cogito ergo sum'dur.

“Varlık'ı bütün olarak tasavvur etmek, aydınlanmaya kadarki dönemde, İnsanın var-olan bütünden ayrı bir var-olan olarak tasavvur edilmediği anlamına gelecektir. Öyle ki, düşünen özne olarak insan ve karşısında açıklanmayı bekleyen nesneler âleminin tasavvur edilişi, Descartes ile birlikte yeni bir metafizik tanımının ilk adımı olarak algılanacaktır" (Küçükkaya, 2018). Descartes' ın bu ünlü önermesi modern dönemin kapılarını ardına kadar açar. Modernleşmenin ortaya çıkışına değin Platonik tezlere kurban edilmiş ve ancak tinsel, tümdengelimci, aşkın kavramların etek ucunda belirme ve biçimlenme fırsatı bulabilmiş olan insanlık, yalnızca kaderine hükmetme hakkı ve imkânından değil aynı zamanda onurundan ve niteliklerinden de feragat etmeye alıştırılmış hatta zorlanmıştır. Modernizm bu akıl tutulması furyasını aklın ve gerçek arayışının yarattı̆̆ 1 cesaret ve ümitle aşmıştır. Özellikle Aydınlanmayla birlikte insanlık yeniden ayakları üzerinde dikilmiş, özgürlüğünü idrak ve ilan etmiştir.

Modernizm uzun bir birikim sürecinin taşkın halini almış sonucudur. Rönesans-Reform döneminden itibaren Batı, refleksivite (düşünümsellik) kavramını yeniden yorumlamaya başlamış ve kendi gerçekliği üzerinde eleştirel bir düşünme sürecine girmiştir.

Refleksivite,“(...)dilin, düşüncenin veya bir disiplinin kendi üzerine dönme gücünü veya yeteneğini anlatan terim. Felsefede ve psikolojide, düşünümsellik anlamında, zihnin kendi üzerine dönmesi, kendisinin hem öznesi hem de nesnesi olabilme kapasitesi, bilincin kendi özbilincine sahip olması durumu. Refleksif Bilinç: Kendi üzerine dönen bilinç. Bununla birlikte ben üzerine düşünüme bağlı olmayan, özne ve nesne ikileminin söz konusu olmadığı, kendi kendinin bilincinden önce gelen bilince refleksif bilinç adı verilir" (Cevizci, 1999, s. 728-729). 
Bireyin edilgenlikten kurtulduktan sonra kendini keşfetmekle yetinmeyip yaşam biçimini kendi dışındaki bütün etkenlerin üstüne çıkarma, davranış biçimini otoriteden bağımsızlaştırma ve sınırsızlaştırma kararlılı̆̆ bireyciliği yüceltince" (Gümüş, 2015, s.1) Batı́nın yeniden ve bir kez daha kendisine dış dünyayı kavradığı kurallar ve yöntemlerle objektif bir eleştiride bulunmasına, kendisiyle yüzleşmesine kapı aralamıştır.

Elbette bu gibi hamleler insanlık tarihi boyunca hem Batı'da hem de Doğu'da çeşitli defalar görülmüştür. Bu anlamda bir yenilik değildir. Ancak Rönesans-Reform sonrasında gelişen ve Aydınlanmayla birlikte doruk noktasına ulaşan refleksivite'yi Antik Yunandaki biçiminden ya da dünyanın geri kalanındaki örneklerinden farklı kılan şey; Aydınlanma filozoflarının öncelikle Batı'ya yani kendilerine tanrı yaratımı bir varlık, eşref-i mahlûkat olarak değil, doğa yasalarına tabi olan ve doğa içerisinde açıklanıp anlam bulan bir nesne olarak yaklaşmalarıdır. Aydınlanmacıların kendilerine dönük eleştirel yaklaşımlarında kullandıkları yöntemler, kabuller ve kurallar tamamen doğanın yasalarından türetilmeye çalışılmıştır. İkinci husus ise kendilerine nesne olarak yaklaşırken aşama aşama Tanrı ile Kilise'den kurtulmaları ve metafizikten arınmaya çalışmalarıdır. Copernicus, Machiavelli, Descartes, Hobbes, Galileo, Locke, Newton, gibi filozoflar ve bilim insanlarıla başlayan bu gayretlerin doruk noktası Kant, Comte, Marx, Darwin ve Freud olmuştur.

Aydınlanma determinizm ve eleştirel düşünme ile girdiği yolda materyalizm ve pozitivizme uzanmış; ontoloji yerine asıl önemli olanın epistemoloji olduğunu ilan etmiş; eğitimi yeni dünyanın temellerine koymuştur. Bu bakımdan "Aydınlanma ruhu, bireyin eğitimini, onu hem ailesinin hem de bizzat kendi tutkularının dayattığı, dar, akılcı olmayan görüşten kurtarıp, akılcı bilgiye ve aklın eylemini örgütleyen bir topluma katılmaya açılmasını sağlayan bir disiplindir" (Touraine, 1995, s.25-26). "Burada akıl, hayatın içinde olan ve hayatı anlamaya çalışıp yorumlayan bir akıl değil, tam tersine, hayatı içine alan ve onu kendince şekillendiren soyut ve mutlak bir akıldır" (İmamoğlu, 2013, s.60-62).

Modernizmin geleneksel döneme kıyasla gerçekleştirdiği bir başka devrimsel hamle ise doğa bilimlerindeki gelişmeyle birlikte ortaya çıkan ve refleksiviteye de akseden açıklama çabasıdır. Zira Antik Yunan mirasından yüzyıllar sonra bilimin kalp masajıyla tekrar hayata dönen felsefe artık tümavarımcı ve olgucu pozitivist bir bilimin ışığında yol almaktadır. Geleneksel dönemde insanın ana gayesi kendisini ve doğayı bir yücelikle ilişkili biçimde 
anlamlandırmak üzerine olmuştur. Tabii ki on binlerce yıl boyunca insan bazı gerçekliklere ilişkin açıklamalar getirmiştir. Ancak modernizmle birlikte gerçekleşen şey öncelikle, açıklama gayretinin kesinlikle bir anlamlandırma gayretine yönelik olmamasıdır. Zira modernizmin temelinde mantık ve bilimsellik bulunur.

"Modern bilime giden yolda insan anlamlandırmadan vazgeçiyor. Formül kuramın, kural ve olasılık da nedenin yerini alıyor. Neden, bilimsel eleştirinin kendini sınadığı son kavramdı; çünkü yaratıcı ilkenin sekülerleştirilmiş en son biçimi olarak eski idealardan yalnızca bu kavram hala bilimsel eleştiriyle boy ölçüşebiliyordu. Töz ile niteliği, etkinlik ile maruz kalmayı, varlık ile var oluşu çağa uygun biçimde tanımlamak, Bacon'dan bu yana felsefenin kaygılarından biriydi, ama bilim bu tür kategoriler olmadan da iş görebiliyordu. ... Bilimselliğe göre düzenlenmiş Aydınlanma açısından [b]içimler çokluğu konum ve düzenlenişlere, tarih olguya, nesneler de maddeye indirgenir" (Adorno ve Horkheimer, 2010, s.22).

Böylece modernizmin büyük anlatısı altında her şey ölçümlenebilir/hesaplanabilir hale gelir ki, bu, her şeyin öncelikle bir nesne olarak anlam kazanmasını gündeme getirir. Modernizmde "birey, her şeyden önce halk deyimiyle hesap-kitap adamıdır. Yaşamını rastlantıya, olağanüstü güçlere dayanarak örgütlemez. Çevresini, zamanı akılla denetleyebilme alanları olarak görür" (Oktay, 2010, s.253). Bu anlamda modernizmin evreninde "[m]odern olmak, bizlere serüven, güç, coşku, gelişme, kendimiz ve dünyayı dönüştürme olanakları vaat eden; ama bir yandan da sahip olduğumuz her şeyi, bildiğimiz her şeyi, olduğumuz her şeyi yok etmekle tehdit eden bir ortamda bulmaktır kendimizi. Modern olmak, Marx'ın deyişiyle 'katı olan her şeyin buharlaşıp gittiği' bir evrenin parçası olmaktır" (Marshall, 2006, s.27). Modernizm nesneyi ölçümlemesi/hesaplanması onun niceliksel gerçekliklerin peşinde olduğunu gösterir. Niteliksel olan onun açısından otantik olandır, egzotik olandır, yerel olandır. Öznenin ön plana çıkmasını sağlayarak nesnelerin otaklığı yani özler üzerinden kurgulanan merkezi yapı ile organizasyona zarar verir. Vurdumduymaz bir görecelikle gerçekliğin dokusunu zedeler. Modernizm bu gibi niteliksel farklılıkların anlam ifade etmesine kapalı bir sistemdir. "Temsil edilebilirlik evrensel bir işlevselliğe dönüşür. Atom temsili olarak değil, maddenin numunesi olarak parçalanır ve tavşan temsili olarak değil, görmezden gelinen salt bir örnek olarak laboratuvarın çileli yolların- 
dan geçer. İşlevsel bilimdeki ayrımlar her şeyin aynı madde tarafından yutulmasına olanak verecek ölçüde akışkan olduğu için, bilimsel nesne taşlaşır" (Adorno ve Horkheimer, 2010, s.28). Bu nedenle bilim ve aydınlanma ikincil özellik olarak yol verdiği özneleşme süreçlerinde pekişen niteliklerin nesne olma durumunu işlevselleştirdiği ölçüde hayat bulmasına olanak tanır. "Bu süreç ötekinin aynı'ya indirgenerek anlaşıldığı, ben ve öteki ilişkisinin bir aynılık ekonomisi içinde düzenlendiği bir süreç" (Levinas, 1969) halini alıyor. “Ötekiliğin diyalektik gelişme sürecine içkin olması her türlü farklılığı ben' in gelişme 'telos' una yani hedefine uyruk kılarak, modernizmin evrensellik iddiasına da dayanak oluşturuyor" (İlter, 2006, s. 4). Zira burada uyruk kılmak, daima özneyi ya da özerk olanları ana gövdeye bağlamakla, hakikati gerçeklikle ilişkilendirmekle ilgili oluyor.

Bu bakımdan modernizmin her yanını kuşatmış olan açıklama çabası tamamen bilimsel, pozitivist ve Aydınlanmacı bir çabadır. Geleneksel dünyayı var eden ve felsefenin de temel sorusu olan neden sorusu yerini böylece nasıl sorusuna bırakmıştır. Felsefede de bilimsel yöntem ve çıkarımların etkileri yayılmıştır. İkincisi, modernizmin açıklama gayreti hakikat peşinde değil, gerçeklik peşinde koşmaktadır. Hakikat epistemolojide gerçeğin insan tarafından algılanışıdır. Yani görecelidir, yorumdan ibarettir. Duyu organlarımızın sağlıklı olması kadar akli kapasite ve imkânımızla da ilgilidir. Gerçeklik ise insanın aklından bağımsız biçimde var olan ve değişmeyendir. Bu nedenle modernizmde "tümel, içlemi dar olması hasebiyle sadece ortak özellikleri dikkate almaktadır. İşte Batı'da gelişen epistemoloji ve bilim tam anlamıyla tümeli esas alarak bilgi problemine yaklaşmış, doğru bilgiden hep tümelin bilgisi diye bahsedilmiştir" (İmamoğlu, 2017, s.1-10). Modernizmin açıklama gayreti işte o değişmez, kati gerçekliğin peşindedir. Üçüncüsü modernizmin açıklama gayreti bir bütünsellik oluşturmaya çalışır. Yani tıpkı bir puzzle gibi, açıklamalarla parça parça aydınlatılmış, gerçekliğe dayalı bir doğa ve insan kavrayışı yaratma amacındadır. Dördüncüsü ve sonuncusu ise modernizmin tanrısal ya da metafizik olan her şeyi tarihsel süreç içerisinde aşama aşama dışarıda bırakan, doğanın ve maddenin yasalarına dayanma eğilimindeki bir açıklama çabası oluşudur. 


\section{Başka Bir Biçim Olarak Geleneksellik}

"Modernleşme, sözlü toplum olma gerçeğinden, yazı ve kayıt toplumuna geçişi ifade eder. ... Modern toplumun bireyi, [karakteristik olarak] duyarak değil, temelde okuyarak öğrenen insandır" (Oktay, 2010, s.251). Geleneksel dünyada bilginin aktarımı sözeldir. Bu nedenle sözlü kültür gelişmiştir. Hayatta başarılı olmak, hem toplum hem de çağın otoriteleri nezdinde makul ve makbul olmak; işini iyi yapmak; iyi bir eş, iyi bir anne-baba olmak; ahlaklı olmak; inançlı olmak ile eşleştirilmektedir. Tüm bunları başarmanın ve huzurlu ve mutlu olmanın yolu ise yaratıcının ve temsilcilerinin öfkesine mazhar olmamak, ataların doğruluğu ve başarısı tarihsel olarak sınanmış yöntemlerini devam ettirmekle mümkündür. İşte bu noktada sözlü kültür yani efsaneler, masallar, örf-adetler, ahlak kurallarını dinlemek, sözün yaratıcı ve biçimlendirici çerçevesinin dışına çıkmamak önemlidir. Sorgulamak, yenilik getirmek, söz dinlememek, risk almak dünya var olduğundan beridir teyakkuz halinde olan türlü fenalığı kaderine davet etmek demektir. Bu nedenle söz bilgi demektir. Bilgi ise kurtuluş ve güçtür. Söze yani bilgiye sahip olan, otorite haline gelmektedir. Söyleyecek sözü olan, hiyerarşide yükselmektedir. Söz sahibi olmak ise ya ruhban sınıfta yer alarak yaratıcının gizli bilgisine erişim sahibi olmakla ya da yaşlılı̆̆ın getirdiği deneyimle ilgilidir. Her iki durumda da söz yani bilgi sahibi olmak iktidar ve otoritenin kaynağıdır. Böyle bir toplumsal yapıda risk almak, bilinenin ve bellenmiş olanın dışına çıkmak tehlikelidir. Bu nedenle geleneksel dünya yaratıcı hakikat ve deneyimin bilgisi üzerine kurulu gizli, gizil ve tekinsiz bir yerdir. Bu dünyanın insanı "...dışındaki evrene kutsal kodlarla bağlandığı ... (bir) topluluk halidir" (Yılmaz, 2005, s.41). Bu dünyada söz gümüş, sükût altındır. Buyruğa kulak asılmalı, yaşlıların engin deneyiminden faydalanılmalıdır. Zira geleneksel dünyada hayat, bir mekâna sabitlenmiş olarak doğaya ayak uydurmaya çalışmakla geçmektedir. Geleneksellik doğa karşısında mekâna sabitlediği insana sabretmeyi ve söz dinlemeyi öğretmektedir. Sabretmenin temel bir düstur olduğu toplumlarda kadercilik ve hiyerarşilerin cirit attığı inançlar egemendir. Bu nedenle geleneksel dünyada ayakta kalmak iktidar ve otorite ilişkileri boyunca genleşen çekim halkalarına tutunmak, otorite merkezli temerküz noktalarına dâhil olmakla ilgilidir.

Gelenek deneyimlenmiş olanın üzerine kuruludur. "Gelenek bir toplumun köklerine ait izler taşımakta ve hafızasını oluşturmaktadır. Geçmişten 
gelen ... birikimle toplumların beraberliklerini kuvvetlendirdiğini söyleyebiliriz. Yasalaştırılmış ya da resmileştirilmiş bir durumu olmayan geleneğin aklın ve bilimin ötesinde yaptırım gücünün olduğu bilinmektedir" (Şimşek, 2017, s.161-178). Bu açıkça doxa'ya işaret eder ve bu bağlamda tümden gelimci anlak, evren ve içerisindeki her şey olarak doğa ile insan bir şekilde yüce ve yaratıcı olarak tanımlanmış bir figürün (tanrı, ruh, doğa vb.) yaratımı haline getirir. Bu yaratım içerisinde neden-sonuç ilişkilerini birbirleriyle etkileşime sokarak yorum yapabilen ve çıarımlarda bulunabilen tek varlık olarak insan, her halükarda üstün varlıktır. Bazı canlılar yaratıcıları temsil etmekle birlikte, doğanın vasatı içerisinde insan, üstün olandır. Tüm bir doğa ve dolayısıyla yaşam da yaratıcı gücün iradesinin ve hikmetinin soluk bir yansımasından ibarettir. İnsan yaşamı boyunca doğa ile ne kadar temas eder, ne kadar çok şey yaşar, ne kadar çok gözlemde bulunur ve söz dinlerse o kadar bilgi sahibi olacaktır. İnsanın yaşamın bilgisine sahip olması demek yaratıc1nın eseriyle o kadar çok temas etmesi, buluşması; onu o denli çok tanıması, öğrenmesi, düşüncede ve histe o kadar çok anlaması, deneyimlemesi demektir. Bu nedenle geleneksellikte makbul olmak tekrarla, gözlemle ve itaatle ilgilidir. İnsan yaşlandıkça tekrarları, gözlemleri ve söze dayalı bilgisi yani genel anlamda deneyimi de artacağından tanrının kelamı yani bilgisine ilişkin birikimi de artacaktır. Bu nedenledir ki toplumsal yaşam içerisinde yaşlıların yaratıcının bilgisine ilişkin deneyimlerine ve birikimlerine hürmet edilir.

Öte yandan ruhban sinıf da (rahipler, büyücüler, kahinler vb.) yaratıcı ile doğrudan bir erişime sahip olduklarından ve nitelikli, üst boyutta gerçekleşen bir ilişkiye girebildiklerinden bilgi sahibidirler. Dolayısıyla yaşlılara gösterilen saygı ve ilginin aynısını hatta daha fazlasını hak ederler. Yani tanrının bir yerde doğadaki sesi, eli, habercisi, kılavuzu niteliğindedirler. Sahip oldukları bilgi ve nitelikler yaşlıları ve ruhban sınıfını kendiliğinden biçimde bir iktidar kaynağ 1 haline getirir. Burada yaşlılara ve ruhban sınıfına gösterilen hürmet aslında yaratıcının bilgisine gösterilen hürmettir. Bu nedenle yaşlılar ve ruhban sınıf kalabalıkların gözünde yaratıcının olaylar ve olgular üzerinden somutlaşan ve yansıyan kelamının yani bilgisinin deşifre edicileridirler. Doğa içerisinde şifreli halde bulunan erdemin ve hidayetin bilgisi yaşlıların ve ruhban sınıfın rehberliğinde ve kontrolünde, onlara itaat ve hürmet ederek edinilebilirdir. 
Ancak tam bu noktada belirtilmesi gereken önemli bir fark da mevcuttur. Yaşlılar deneyime dayalı bir ermişliğe dayanırken, ruhban sınıf doğa olaylarını yorumlamakta hatta doğrudan tanrının kelamını okumaktadırlar. Bu onları yalnızca sözü dinleyen, izleyen olmaktan çıartarak okuma bilen, yazıyla ilişki kuran kimseler haline getirir. Dolayısıyla ruhban sınıfı sadece yaşlı olmaktan kaynaklanan toplumsal statünün üzerinde bir yerde konumlanır. Bu durum insanlık tarihinin ilerleyen safhalarında ortaya çıkacak olan devletin teşekkülünde kurucu ve biçimlendirici nitelikteki önemli bir ayrıntıdır. Zira şamanların, paganların vd. düşler, rüyalar, fallar, doğa olaylarını okuyarak bildirdikleri şeyler ile (okuma-yazmanın tüm dünyada ayrıcalıklı bir kesimin uğraşı olduğu dönemlerde) semavi dinlerde tanrının sözlerinin yazıya dökülmesi ve bu yazının yorumlanmasıyla ulaşılan bilgiler toplumsal katmanlar arasındaki çizgileri derinleştiren, hiyerarşileri besleyen, iktidarları tahkim eden bir sonuca neden olur. Dolayısıyla yaratıcı olana yakınlaşmak, onunla ilgili hale gelmek iktidar ve otorite doğurur. Bu nedenle yaratıcı olan iktidarın doğası içerisinde ortaya çıkan bir dizi tahakküm mekanizması nedeniyle geleneksel yaşamın tam merkezine gelmiştir.

Yazıyla yani metinle/sözle ilişki kurmak, yaratıcı güçle ilişki kurmak anlamına gelmektedir. Yaratıcı gücün bilgisi ve erdemi, yönetici sınıf haline gelen kesimlerin elinde toplumsal düzenleme aracı olarak ahlak ve normlara dönüşmüştür. Böylece ahlak ve toplumsal normlar yaşamın gerçeklerinin ötesine atıf yapan, insan doğasından kaynaklanan heyecanları, arzuları, korkuları, hırsları dizginlemenin ve/veya azdırmanın yani insanı ve toplumsal yaşamı kontrol altına almanın bir aracı olarak belirginleşmiştir. Erdemin ve etiğin insana aşkın olmasının ve toplumsal gerçekliğin nasıl olması gerektiği sorusuna verilen yanitın metafizik olandan ayrilamamasının nedeni budur. Oysa insan "modern dünyada kendisi değerlerin temeli haline gelir, çünkü ahlaklılı̆̆ın ana ilkesi özgürlük kendi kendisinin ereği olan bir yaratıcılık olmuş ve tüm bağımlılık biçimlerine karşı çıkmıştır" (Touraine, 1995, s.234). Geleneksellikte olması gereken, olana üstün kılınmıştır ve onu anlamak ve anlamlandırmak için kılavuz olarak ilan edilmiştir. Böylece metin, insanı aşan, onu tanrısal mertebe ile etkileşime geçirme yeteneği olan, insana kurtuluşu ve mutluluğu vaat eden kusursuzluğun şeması, ilahi idelerin idrak edilebilir nitelikteki yansımasına dönüşmüştür. Metin yapay ve doğaüstüdür; insanın tanrılaşma arzusunun bir ifadesidir. 
Geleneksel toplum deneyime dayalı rutinlerin istikrarlı tekrarına dayandırıldığından yaşamın akışında meydana gelen değişimleri yordamak konusunda yeterince başarılı değildir. "Bu tip toplumlar içerisinde bulunan bireyler arasında çok sıkı bir iletişim ve buna bağlı olarak yüz yüze iletişim yoğun olarak yapılmaktadır. Dinin ise yönlendirici ve hayatı kapsayıcı bir değer olarak dokunulmazlığı olan bir alana tekabül ettiği söylenebilir. Ekonomi daha ziyade tarıma dayalıdır. Eğitim ve öğretim sadece belli seçkinlerin elindedir. Toplumsal değişme yavaş olup birkaç nesli kuşatır"(Kirman, 4, 2004, s.88).

Dolayısıyla doğa koşullarındaki veya altyapıdaki değişim ve dönüşümlere de yeterli bir yanıt üretemez. Geleneksel toplumlar, değişim ve dönüşümlerle başa çıkmak konusunda kendi deneyimlerinden yararlanamadıkları veya umdukları sonuçları alamadıkları zaman gösterdikleri ilk tepki gözlerini başarılı olan toplumlara dikmek ve onların deneyimlerini benimsemektir. Nitekim İslam'ın özellikle ilk dönemlerinde Orta Doğu karşısında geri kalmış olan Hristiyan Batı veya özellikle Aydınlanma sonrası Hristiyan Batı karşısında Müslüman Doğu ya da Batı karşısında geri kalmış olan Japonya bu duruma en iyi örneklerdir. Tüm bu ileri geri ilişkilerinde değişim ve dönüşümün altyapısal nedenleri açıklanamadığı için değişmek arzusu bir tür şekilciliğe indirgenir. Şekilcilik ise öncelikle radikal kılık kıyafet değişimleri, normlarda ve yaşam rutinlerinde değişiklikler, bürokraside ve hukukta değişiklikler olarak kendini gösterir ve forma yönelik olarak kalır.

Şekilcilik geleneksel toplumların gelişmesi bağlamında yüzeysel olmakla birlikte toplumu yeni olanla tanıştırması bakımından zorunlu ve kaçınılmazdır. Zira şekilcilik geleceğin dünyasının bir fragmanıdır. İlgi ve istek uyand1rır. Geleneksel toplumlarda yaşanan her dış kaynaklı değişim mecburen öncelikle yoz ve eğreti bir biçim almak durumundadır. Gelenek tecrübeye dayalı oluşundan kaynaklanan yoğunluğu nedeniyle geleceği esir alır, toplumun kıpırdanmasına izin vermez ve toplumu otantikliğin basmakalıp durağanlığına hapseder. "Böyle bir toplum ise kaderci ve pasif insanlar yetiştireceğinden, gelişmenin dinamiği için çok önemli olan girişimci, yaratıc1, sürekli ilerleme arzusunda olan bireyleri yeterli miktar ve seviyede yetiştirememektedir. Bu durumun sonucu olarak ise, halkın kendi kendini idare edebilmesi için çok önemli olan özgür tartışma, karşılaştırma, dinsel metinler dahil her şeyi sorgulayarak gerçeğe ulaşma kültürü gelişememektedir"(Er, 2014, s.423). 
Dolayısıyla geleneksel toplum evrimsel bir değişim gösterir. Yeni olanın eskinin aşkın yapılarını ve kavramlarını aşındırmadan, bunlardan kaynaklanan iktidar ve otorite ilişkilerine zarar vermeden tanzim edilmesi gerekir. $\mathrm{Bu}$ nedenle Aydınlanmanın geleneksel dünyadaki (Avrupa) etkileri çok sarsıcı olmuş ve hiç hoş karşılanmamıştır.

\section{Aydınlanmacı Perspektiften Doğu'nun Modernizm Sorunu ve Bir Kaçış Rotası Olarak Çağdaşlaşma}

Özneliğin kuruluşuna ilişkin yapı, ikincil terimin hiçbir zaman hâkim olan birincil terim gibi bir özne olamayacağını ifade eder. Yani modernizmin ikiliğinde Bacon'dan beri bilen ve bilinen ayrışmıştır. Bacon (1999, s.22-27) yöntemli-ampirik bilgiden önceki bilgileri tanımlarken eski bilgiyi insanları yanlış biçimlendiren, yönlendiren bir hatalar zinciri olarak görerek dört farklı idolleştirme altında toplamış (Kabile idolleri, Mağara idolleri, Çarşı-Pazar idolleri, Tiyatro idolleri) ve aslında bireyin farklı unsurların etkisiyle inşa edilmekte olan bir olgu olduğuna vurgu yapmıştır. Geleneksel dünyanın insanı bu kurgu çerçevesinde bilinendir. Tanrı tarafından bilinen, ruhban ve yönetici sınıf tarafından bilinendir. Bu tümdengelimci bir anlağ1 empoze eder. Oysa bilimsel bilgi ve ona dayalı toplum tümevarımcı olmalıdır. "Tasim, önermelerden, önermeler de kelimelerden ibarettir; kelimeler ise kavramlara işaret eder. Bu nedenle, eğer bütünün temelini oluşturan kavramlar karışık olarak ve şey'lerden dikkatsizce soyutlanmışlarsa üstyapıda bir sağlamlık yok demektir. Öyleyse bizim tek ümidimiz gerçek tümevarımdır" (Bacon, 1999, s.10). Bilgiyi gücün yolu ve aracı kılan şey, işte budur. Yani bütünün bilgisine en çok kim sahipse o avantajlı konumda olacaktır. Dolayısıyla bilen, sahip olduğu bilgiden kaynaklı okuma ve yorumlama iddiası nedeniyle bilinen üzerinde egemendir; gerçek manada özne olma fırsatı, modernizmde, yalnızca bilene aittir. Eğitim ile refah arasındaki ilişki bu noktadan doğar.

Modernizm ikilikler aracılı̆̆ıyla kapsama yeteneği sayesinde “...her öğretiye dayanak olacak olan epistemolojik ve tarihsel bir bilinç zemini" (Duran, 2008, s.138-140) haline gelir. Bu bakımdan Aydınlanmacı temeller üzerinde bina olan modernizm açısından ölçmek ya da "bir şeyi adlandırmak, insanın kendisini özne, ötekini nesne olarak tasarlamış olması anlamına gelir" 
(Jacques, 1998, s.74). Bu da modernizmin Kartezyen yapisiyla ilgilidir. Descartes' in kendi ifadesiyle, "incelemek istediğimiz şeylere, ne başkalarının düşündüğünü ne de kendimizin sandığımızı değil, açık ve apaçık olarak görebildiğimizi (sezgisini edinebildiğimizi) yahut da şüphesiz bir deduksiyon ile çıkarabildiğimizi aramak lazımdır; çünkü bilim başkaca elde edilemez" (Descartes, 1989, s.10). Amaç, bilen özne olarak “...her kişinin usunu iyi kullanması için izlemesi gereken yöntemi öğretmek değil, ama yalnızca benimkini hangi biçimde kullanmaya çalıştı̆̆ımı göstermektir" (Descartes, 2015, s.27). Yani gerçekliği özneden itibaren kurmak; yönteme dayalı bilgi kullanımı ve tümevarımcılıktır. Böylece şüpheci ve tümevarımcı bilen-bilinen ikiliği temelinde gerçekleşen epistemolojik bilgiye dayalı ayrışma kendiliğinden biçimde karşıdakini tanımlayan, onu yönlendiren ve biçimlendiren bir hale gelir.

Batı Aydınlanma ile birlikte episteme üzerinden ilerlediğinden, modernizm bağlamında bilen konumundadır. Üstelik yalnızca egzotik olanı, otantik olanı değil; kendisini de bilendir. Cogito ergo sum'un marifeti buradadır. Bu sayede Batı, öznenin kendi varlığı da dahil her şeyin sorgulanması ve ispatlanması gerektiğini varsaymış ve bunu mantık bilimi ile matematiği eşleyerek başarmıştır. Tek gerçek bilgi yöntemli şekilde elde edilmiş bilgidir. Bu bilgi öznenin şüpheci gerçeği arama çabasını içerir. Bu nedenle Aydınlanmadan beri modernizm hesaplamacı ve ölçümcüdür. Bu, ölçümlenemez olan niteliği devre dışı bırakır. Bu bakımdan otantik ve yerel olan, pozitivizmin de katkısıyla, merkezi ve bilimsel olanın boyunduruğu altına girer; Doğu'yu Batı için nesneleştiren ve onu agresif gösteren budur. Doğu, Batı için mutluluk ve refahın temelinde yer alan gerçeğin bilgisine ulaşılacabilecek bir nesne durumundadır. Didiklenir, araştırılır, parçalanır ve kullanılır.

Modernizmle birlikte Batı'da olgucu perspektif yaygınlaşır ve toplumsal ilişkiler alanı, ahlak ve siyaset bu perspektifte yani olgusal olanın ölçümlenebildiği noktada biçimlenir. Machiavelli ${ }^{1}$ bu noktada siyaset ile ahlakın ayrıştırılmasını sağlayarak laikliğin ve modernliğin ilk savunucularından biri olmuş; pragmatik felsefeye giden yolun kapısını aralamıştır. Batı' da "[b]ilimin

\footnotetext{
${ }^{1}$ Ahlak dinin kurumsal yapısının hegemonyasında biçimlendiğinden siyaseti ahlaka tabi kılmak dünya işlerinin ve yönetimin dinin hiyerarşik üstünlügüne tabi olmasını kabul etmek anlamına gelir. Ancak ne zaman ki siyaset ile ahlak ayrıştırılırsa o zaman modernizmin temel parametrelerinden biri olarak inancın özel alan ve bireye özerk olmasının önü açılır. Yönetim ve toplumsal yaşam dinin ve ruhban sınıfın boyunduruğundan kurtarılır. Bu konuda Machivelli’nin açıklamaları için bknz: (Machiavelli ve Niccolo, 2008)
} 
gerçek amacı ve görevi; akla uygun, eğlendirici, saygıdeğer ya da etkili söylevler veya birtakım kolay anlaşılır uslamlamalar değil, icra etmek çalışmak ve yaşamı daha donanımlı ve kolay hale getirecek önceden bilinmeyen ayrıntıları keşfetmektir" (Bacon'dan akt Adorno ve Horkheimer, 2010, s.21). Buna karşın Doğu tümdengelimci bir iktidar yayılmasının ataleti altında 'razı gelir'. Çeker, katlanır, sebat gösterir; çileci ve kadercidir. Doğanın yasası tanrının yasasıdır ve onu değiştirmeye cüret etmek tanrıya itirazdır. Birey, üstesinden gelemediği olaylarla baş etme mücadelesinde kendini korumak için sorumluluktan kaçınma eğilimine girebilmekte ve bu nedenle sıkı bir kaderci anlayışa sahip olabilmektedir. "İnsanlar üstesinden gelemeyecekleri olaylarla mücadelede kendi kendilerini incitmemek için bazen sorumluluk duygusundan kaçma eğilimi içerisine girerler. ... [B]u husus bazı kişilerde sorumluluklardan kaçıp olayın nedenini kadere bağlayarak kendi özsaygılarını kurtarma işlevi görmektedir. Bu durum daha çok olayların oluınsuz sonuçlarının sorumluluğundan kaçma şeklinde görülür."(Kuşat, 2000, 110).

"Doğu bu anlamda kaderciliği daha ziyade genel manada kişisel sorumluluğun azaltılması olarak algılar"(Maher, 1909). Bir tür kendini avutma, çaresizliğe merhem olma durumu vardır. Bu nedenle Batı episteme istikametinde ilerlerken Doğu doxa'nın mekânı olarak kalmış ve ekonomik ve bilimsel gerçeklikten koparak tümden gelimci kanıların bir yumağı haline gelmiştir. Bu yumak içerisinde merkezdeki tanrı her şeyin anlamlanmasını ve bir arada kalmasını sağlayan kilit taşı gibidir. Gerek toplumsal alanda gerekse de doğada bir amaçlılık hali mevcuttur ve cevabı verilemeyen soruların doğurması muhtemel dehşet bu şekilde aşılır. Aydınlanmacı perspektifte ele alındığında Doğu ile Batı'yı birbirinden ayıran en önemli unsur kaçınılmaz biçimde refleksivite olmak durumundadır. Bu iddia Doğunun dinin, Batı́nın ise felsefenin evi olmasını anlaşılır kılar. Zira yazı içerisinde daha önce de dile getirildiği gibi felsefe aslında refleksivitenin disiplinidir. Doğu toplumları Batı'da öznenin kendi üzerine düşünme süreci olarak açıkladığımız refleksivite aşamasına hiç geçememiştir. Bu nedenle Doğu felsefeye yabancıdır. Doğu'da felsefe adı altında gerçekleşen her faaliyet -kurumsal ya da değilinançların şemsiyesi altında ve/veya inançların toplumsal yaşama katılımı noktasinda onlara destek olmak için var olmuştur. Oysa özellikle kurumsallaşmış ve politikleşmiş, evrensellik iddiası taşıyan dinler açısından geniş Doğu coğrafyaları adeta bir ana rahmidir. Bunun nedeni geleneksel yaşamın 
paradigmasından kopuşu sağlayamadığından Doğu'da öznenin hiçbir suretle doğanın ve kendisinin gerçekliği içerisinde ele alınmamasıdır. Bir noktada Batı'nın bilim, sanat, üretim-tüketim ilişkileri ve devlet yapılanmasında Aydınlanma sonrası episteme üzerine yoğunlaşması karşısında Doğu'nun yaşamı gerçeklik zemininden kopuk şekilde doxa üzerinden okumaya devam etmesi söz konusudur. Bu farklılık, iki dünyanın varoluş zeminlerinin kökten ayrilmasina neden olur.

“Doğu'nun modernleşme sürecinde yaşadığı değişim bir yamalama örneği olarak adlandırılabilir, çünkü Doğu toplumları, Batılı insanının geçirdiği modernleşme sürecinin benzerini tecrübe etmemiş, büyübozumunu gerçekleştirememiştir. Bu sebeple Doğu'nun tepkisi, bünyesel bir çatlamanın dişa vurumlarını yansıtan yamalı birtakım öneriler olarak adlandırılabilmektedir. Aynı tarihsel akışın izlerini yansıtmayan iki dünyanın varoluşunun yarattığı dilemma, Doğu'nun da şu anda yaşadığı kaotik değişim sonuçlanarak dengeye oturuncaya kadar sonuçlanmayacak ve etkilerini günümüz dünyasında her daim hissettiğimiz 'kültürel şizofreninin' en önemli beslenme kaynakları olmaya devam edecektir"(Shayegan, 1991, s.101).

Doğu'da özne her daim kutsal olanla ilişkisi içerisinde değerlendirilmiş, hep bir yücelik ilişkisi içerisinde düşünülmüştür. "Modernizm öncesi kadim kültürlere baktığımızda görürüz ki, o kültürlerde varlık âlemi kategorilere ayrılmayıp, çeşitli varlık mertebeleri birbirleri ile ilişkili ve anlamlı bir bütün oluşturmakta, varlığın merkezinde ise 'kutsal' olan bulunmaktadır" (İmamoğlu, 2017, s.1-10). Bu bağlamda Batı, insan nedir sorusuna insanın tanrısal olanla bağını kopartarak "politik hayvandır" yanıtı vermiştir. Bu yanıt insanı doğanın gerçekliği içerisinde, kendi varoluşunun farkındalı̆̆ıyla kucaklamaktadır. Oysa Doğu'da insan nedir sorusuna verilen yanıt her defasında doğruyla yanlışı ayırt etme melekesine sahip, vakar sahibi bir mahlukattır biçiminde olmuştur. Hatta bu yanıt İslami gelenek içerisinde "eşrefi mahlukattır" mertebesine kadar tırmanmıştır. Oysa doğa içerisinde ahlak ya da doğruyanlış gibi kavramlar yoktur. Dahası doğada böyle kavramlar aramak abesle iştigaldir. Onun düzeni tam da her canlının en temel çabası olan hayatta kalmak üzerinedir. $\mathrm{Bu}$ anlamda bir aslan bir ceylan yavrusunu yediği için ahlaksız ilan edilemeyeceği gibi en güzel çiçekleri yemek için diğerlerinin önüne geçmeye çalışan bir keçi de hatalı davranmamıştır. Bu tür idealize edilmiş kavramlaştırmalar toplumsal yaşamı organize edebilmek ve düzeni sürdü- 
rülebilir kılmak için icat edilmiştir. Ancak ne var ki, bir noktada bu kavramların herkesi kapsayıcı ve yaptırım gücüne sahip hale gelebilmesi için aşkın bazı sembollere, efsanelere, korku-ödül düzeneklerine bağlanmaları gerekmiştir. Bu yol izlendiğinde anlamlandırma ağır basar ve tecrübe, nasihat, ahlak, inanç önemli hale gelir.

$\mathrm{Bu}$ çerçevede şu iddiada dillendirilebilir: İnsanlar korkuya kapıldıklarında iki farklı tepki gösterirler. Tepkilerden biri umursamamak veya bir yüceleştirmenin şemsiyesine, koruyuculuğuna iltica etmektir. Böylece gerçek yadsınır ve sorunla başa çıkılır ve kaygı sonlandırılır. Diğer tepki ise korkmak ve bu korkuya neden olan şeyi hızla açıklayarak ya onu kontrol altına alacak çözümler üretmek ya da ondan korunmayı sağlayacak şeyler geliştirmektir. $\mathrm{Bu}$ yol tercih edildiğinde yasa ve hukuk ortaya çıkar. Hukuk yaşamda karşılaşlan somut sorunlara yanıt üretmeye odaklanır ve toplumsal ilişkiler de ihtiyaçlar ve gereksinimlerden türeyen iktisadi yapı ve yasaya göre düzenlenir. Sekülerleşme baş gösterir.

Oysa Doğu'nun insan nedir sorusuna ürettiği yanıt hiçbir biçimde onun tanrı (ya da yaratıcı enerji, evren ve tanrısal niteliklerin atfedilmiş biçimiyle doğa) ile olan ilişkisinden soyutlanamaz. Dolayısıyla Doğu için tanrı, tüm bir toplumsal yaşamı kuran, insanın ölüm ve yaşamla olan ilişkisini düzenleyen kurucu arkhedir. Böyle bir zihin haritasında modernizmin yarattğ fuili durum olarak modernlik, Doğu'ya, “... zorunlu olarak yabancı, güçlü ve esas itibarıla da kendi yaşamını ve sorumlu bulunduğu diğer bireylerin yaşamlarını alt üst eden zorlayıcı bir kuvvet olarak gözükür. Böylesi bir durumda modernliğin iç yapısını olumlu bir biçimde bireye sunması olası değildir. ...[B]ireyin modernlikle tanışma ve modernliğin ne olduğunu kavrama derecesi son derece düşüktür" (Berger, Berger ve Kellner, 2000, s.136).

Modernizmin ontolojik temellerinden ve süreçlerinden yoksun olan Doğu, modernizmle ilk karşılaşmasını sömürgecilik, yağma ve savaşlarla yaşamıştır. Bu travmatik karşılaşmalar neticesinde Doğu, yenilgilerin ve başarısızlıkların kaynağı olan (bilen-bilinen ayrımı temelinde yükselen) ileri-geri ikiliği tarafından emilmiş ve modernleşme yoluna girmiştir. Ancak ne var ki, modernleşmenin -modernizmin süreci olarak okunmak istenmesine karşınimkansızlığı modern kavramının güncel ve çağdaş olana bir vurgu olduğu ifade edilerek yani felsefi ve toplumsal süreçlerinden ve özünden koparılarak; basitçe bir çağdaşlaşma meselesi olarak yeniden yorumlanarak aşılabilmiştir. 
“Batıdışı modernlik kavramı, Batı'yı merkezden kaydırarak modernlik üzerine Batı́nın kıyısından yeni bir okuma ve dil üretmeye çalışmaktır, yani yerel olguların analizinin evrensel bir dil kazandırabileceğine işaret etmektir [...] [B]atı dışı toplumları ikinci el bir modernite anlatısıyla çözümlemek yerine, Batılı olmayan toplumları modernite sorununun merkezine taşır" (Göle, 2004, s.56-67). Böylece Doğu'nun “[m]odernizmi çağdaşlaşma anlamıyla değerlendirerek akla hep yeni, yeni olan, eskiden uzaklaşmış anlamına geldiğini ve kavramın yakın zamanın eş anlamlısı olarak kullanıldığını söylemek mümkündür" (Batu ve Tos, 2017, s.993). Böylece Doğu'nun gözünde modernleşme ile çağdaşlaşma birbirine eşitlenir. Oysa ki, modern ile çağdaş farklı anlamları haizdir. Dolayısıyla İngilizcedeki haliyle comtemporary ile modern $^{2}$ arasındaki ayrımdan türeyen vurgu farklılığından yararlanarak Doğu, modernleşmeyi çağdaşlaşmaya eşitler. Bunun anlamı modernizmin coğrafyaya göre farklı yorumlar kazanabileceği, farklı biçimler alabileceği ve kendine özgün bir görünüm sergileyebileceğidir.

O halde Batı'nın ahlakı, kültürü, toplumsal yapısı gibi değerler setinin parçası olan unsurlar teknik, idari ve ekonomik gelişmelerden ayrılabilir. Somut durumda kolayca fark edilen ve ayrışan her şey "kararlı bir liderlik" ve "planlı bir uygulamacilı" altında aynen "resmedilebilir". Çağdaşlaşma Batı'yı Batı yapan görünür şeylerin tatbikiyle bilen-bilinen ayrımına yaslanmış hiyerarşi ve kötü gidişatı bertaraf edebilir. Bu yorumlama ve yeniden üretme çabası Batı'nın modernizmin merkezindeki ontolojik konumunu geçersiz kılmaya yöneliktir. Bu açıkça şekilci bir çağdaşlaşma bir başka ifadeyle Batılılaşmadır. Oysa bu düşünce dahi modernizmin araçsal aklından, Pozitivizmden, Oryantalizmden ve Aydınlanmadan bir esinlenmedir ve aslında bilen-bilinen kurgusundaki rolün dolayımlamayla bir kabulünden ibarettir. Modernizmin himayesindeki Batı'nın mantıksal ve bilimsel avantajına karşı yorumlanabilir olan ve merkezkaç etkisi nedeniyle tamamen bir kopuş sağlamasa da uzaklaşma getirebilecek olan estetik alanında varlık şansı bulmuş bir itiraz ve itiraftır.

\footnotetext{
${ }^{2}$ Oxford Ingilizce Sözlük'te contemporary kelimesi tamamen çağdaş ve türevi açıklamalarla izah edilirken, modern kelimesi günümüze ait olan çağdaş dışında gelenekten farklı olma arzusu, teknolojik, sanayi devrimi sonrasına ait olanla ilişkili izahatlerle karşılanmıştır. Bu nedenle çağdaş kelimesi ile modern kelimesi arasında modernizme dayanmakla çağın gereklerine uygun yaşamak arasındaki farktan kaynaklanan bir fark vardır. Dolayısıyla günümüzde çağdaş olmak demek post-modernden de öte insan-ötesi olmayı da gerektirebilir. Oysa modern olmak her daim modernizmin paradigmasıly ilişkilidir. Bknz: https://www.oxfordlearnersdictionaries.com/
} 
Doğu'nun gözünde "[m]odernist bilimin doğanın hangi unsurlarını tanımladığı ve açıkladığı, bunların nasıl açıklandığı, bir bakıma Avrupa yayılmacılığının bilinçli amaçları ve bilinçaltı çıkarları doğrultusunda seçilmiştir. ... Sonuçta, Üçüncü Dünyanın bir parçası olan Doğu'da uygulanan kalkınma politikaları (Kuzey teknolojilerinin ve onların bilimsel rasyonalitesinin transferi), Birinci Dünya'dan Üçüncü Dünya'ya 'hastalıklı bir kalkınma' getirmiştir. Batı teknolojilerinin ve Batı bilimlerinin transferi ve ötekilerin/ötekileştirilenlerin reddi, sahip olunanlar-sahip olunmayanlar, (bilim ve teknolojiden) yarar sağlayanlar- maliyetine katlananlar arasındaki uçurumu derinleştirmiştir"'(Serdaroğlu, 2010, s.174-175).

Doğu Batı'nın bilen, etken, saldırgan, sömürgeci karakterinden doğan ileri pozisyonun sanayi devriminden kaynaklandığını; gelişmenin temelinde ticaret, bilim ve teknik olduğunu düşünmüş, modernizmin felsefi ve sosyolojik temellerini yeterince dikkate almamıştır. Sorun bellidir: Ekonomik ve teknik geri kalmışlık. O halde reçete de bellidir. Tıpkı bir eczacıdan ilaç alır gibi Batı'dan söz konusu gelişmeleri getirip benimsemek. Yoksulluk, gelişmemişlik, geri kalmışlık hep bilgiyi kullanmayı bilmekle ilgilidir. Bu bağlamda "[y]oksullukla kadercilik arasında da ilişki bulunmaktadır. Düşük umut, yüksek ve düşük gelir de yüksek kadercilik eğilimi ile ilişkili bulunmuştur" (Cidade vd. 2016, s.55-56). Böylece Doğu coğrafyalarında eğitim ve kalkınmacılık yoluyla refah artışı sağlamak modernizme bir direniş, durumu eşitleme yöntemi olarak yorumlanmış ve fetişleşmiştir.

Episteme'ye dayalı Batılı Aydınlanma düşüncesi Doğu'da kendine aradığı yeri bulamaz ve bu durum bireyin ortaya çıkışını ve kendisi üzerine düşünümünü sakatlayarak modernizmin düşünsel köklerinden ayrık ve kopuk şekilci bir Batı tipi kalkınmacilık olarak algılanmasıyla savrulur. Bunun sonucu açıktır: Gelenek ile modern arasında parçalanmış, demokratikleşemeyen, akıldışı bir toplumsal yaşam. Zira "[m]odernizasyonun son derece önemli bir vektörü, modernliğin sağladığı ekonomik çıkarlara uzanan bir yoldur, gereçtir" (Berger, Bberger ve Kellner., 2000, s.149). Bu durumda Doğu'nun modernizm ve modern olanla karşılaştığında ortaya çıkan sonuç felsefi köklerinden uzak yoz bir pragmatizm, büyük anlatının varlığından koparak hedonizme savrulmuş bir bireycilik ve amansız bir kapitalizmdir.

Doğu'da insanın varoluşuna ilişkin büyük sorular tanrısallıktan ayrıştırılamaz. Bu, Doğu'nun doğaya ve doğayla kurduğu ilişkiye içkin olarak biçim ve içerik kazanan bir durumdur. Zira Doğu'da modernizmin tam aksine - 
Aydınlanmacı perspektiften yorumlandığında- bilen tanrı, bilinen ise insandır. Yani insan pasif ve edilgen olan; tanrının tasarruflarının konusu olandır. Doğu ontolojisi doğayla bir uyumluluk üzerine kuruludur. Doğanın insan varlığını biçimlendirici gücünü tanrısal kudretin ve yazgının bir tecellisi olarak yorumlar. Tanrı, insanlarla doğa aracıllğıyla etkileşimler kurmakta, iletişime geçmektedir. Bu mesajların birçoğu açık seçik olmakla birlikte, bazılarını anlamak için tanrının yolunda tam bir teslimiyetle tefekkür ve sebat etmek gerekir. Mekâna sabitlenmiş bir hayat tarzında sabır ve kadercilik bu nedenle inanç odaklı dünya okumalarına egemen olur. Ruhban sınıf bu meşakkatli yolu yürümeyi başarmış olan kişilerdir ve tanrının ağırlığ 1 çiğ ruhları ezebilecek mesajlarını herkesin anlayacağı bir forma dönüştürür. Böylece inancın sembolizmle bağı kurulur. Bu anlamda ruhban sınıf, (ister monoteist olsun ister çok tanrılı) inançların doğanın koordinat düzlemleri boyunca anlamlandırılması, yaygınlaştırılması, sembolleştirilmesi, resmedilmesi ve kendi ontolojisini inşa etmesinden sorumludur.

Doğu kültürünün uyum kaygısı onu grilerin, kabullenişlerin, ara yolların, sürekliliğin, yavaşlı̆̆ın, döngülerin alanı haline getirmiştir. Bu nedenle Doğu medeniyeti bir hem ... hem medeniyetidir. Bu orta yolcu yaklaşım gerçeği maskeleyen bir bakış açısı geliştirir. Toplumsal gayret açıklama yerine anlamlandırmaya yönlendirildiğinden doğa ve insanın gerçekliğiyle karşı karşıya gelmek değil bunların etkileşimden doğan anlamlar önemlidir. Anlamlandırma her tür kaygıyı bastırır; açıklamaların doğurması muhtemel yeni soruları ve huzursuzluk hissini daha var olmadan engeller. Yüce bir döngüsellik tüm kâinatı devindirir. Anlam bu devinimin sürekliliğinden doğar ve anlam arayışı da bu döngüselliğin, bu sonsuzluğun yüce bilgisine vakıf olmakla ilgilidir. Tüm dünya bu orta yolculuk, uyumluluk kaygısı ve döngüsellik düşüncesi üzerinden anlamlandırılır. Açıklamak bir ihtiyaç ya da amaç değildir. Açıklamak sadece olayları ya da olguları bu dünyaya bağımlı bir peşi sıralık (nedensellik) içerisinde dizinlemekle ilgilidir; buna hiçbir zaman gerek duyulmaz. Modernizmin kastettiği manada bir açıklama, tanrının yaratımındaki "ilmin" sırlarını keşfetmeye, idrak etmeye cüret göstermektedir. Kesinlikle hoş karşılanmaz. Platon'dan beri insanın erekselliği mana bulmak olarak kabul edilir. Oysa anlamlandırma olayların ve olguların bu dünyayı aşan ve bu dünyanın sınırlılı̆̆ içerisinde algilanması mümkün olmayan tanrısal bir aşkınlık içerisinde kavranmasını sağlar. Kavrayış, inanan için, bütünün parçası olmanın yaratacağı bir huzurla müjdelenmek anlamına gelir. Din ve 
hatta ahlak dahi, bu anlamda, insanın insan olmamaya ilişkin arzusunun, yani onun insan olmanın getirdiği kusurluluk ve sınırlılıkla yüzleşmekten kaçışının, yani tanrı(lara)ya öykünmesinin bir ifadesidir. Devinimin içerisine karışmak, bütünle buluşmak din ve ahlak kurallarına uyabilen ve dünyanın zevklerinden uzaklaşarak meşakkatli bir tefekkür ve terbiye sürecine teslim olabilenler için insan olmanın gerçekliğinin ve sınırlılığının reddedildiği ve aşıldığı noktadır.

İnsan "modern dünyada kendisi değerlerin temeli haline gelir, çünkü ahlaklılığın ana ilkesi özgürlük kendi kendisinin ereği olan bir yaratıcılık olmuş ve tüm bağımlılık biçimlerine karşı çıkmıştır" (Touraine, 1995, s.234). Bu nedenle modernleşme süreci "bireysel düzeyde olgunluk ve kendine yetebilirlik, toplumsal düzeyde örgütlenme ve iktidara talip olma gibi özellikleri içinde barındırır. Modernleşme yönetsel, toplumsal ve siyasal unsurların yenilenmesidir" (Fırat, 2020). "Modernleşme, toplumlarda kurumsal yapılar bakımından da büyük ölçüde farklılaşma ve uzmanlaşma ortaya çıkardı. Bu farklılaşma ve uzmanlaşma ile ilgili olarak, modern özelliklere sahip toplumlarda, bu yapılara dahil olma süreci, ‘akrabalık bağları, bölgesel, toplumsal sınıf veya mevki' ilişkileri gibi sabit bir şekilde formalize edilmedi. İşlerde meydana gelen çeşitlenme sonucu yeni uzmanlık alanlarına gereksinim duyuldu. Bu yeni duruma egemen olan uzmanlaşan roller ise, ailesel bağlar, akrabalık, sınıf, mevki bağlanı vb. yerine, çalışma ve başarma sonucu oluşan 'serbest geçişlilik ilkesi' ile gerçekleşti'(Eisenstadt, 2007, s.12-14).

Oysa geleneksellikte teslimiyet ve kadere boyun eğiş son derece önemlidir; kişinin kendisini yüce bir iradenin varoluşu delip geçen kudretine bırakmak anlamına gelir. İdealler yaratmak bu ortak bilinç dışı gaye üzerinden tüm yolcuları (aynı inancı paylaşanları) birleştirir. Zira yol bir araçtır ve insanı terbiye eder. Aynı hedefe varmak üzere yola koyulanları eğitir, kaynaştırır; bir kültür, birtakım rutinler, davranış kalıpları, tutumlar ve devasa bir dogma oluşturur. Geleneksel bir toplumu ve o toplum içerisindeki insanı idealler ve idealleştirilmiş imgeler ayakta tutar. "Hiçbir şey kendi başına mevcut olamaz. Her şey bütüne bağlı olarak kalır ve özellikle bu bağllık kendisine hayat veren varlıklar söz konusu iken varlığını daha fazla hissettirir. Bireysellik son derece sınırlıdır. Hiçbir şey ve hiçbir varlık izole edilemez" (Berger, Berger ve Kellner, 2000, s.165). Modern anlamda özerk bir birey ortaya çıkmamıştır ve bu nedenle insanlar toplumsal yaşamı düzenleyen kurallara uymanın gerekliliğini açıklanmış bir çerçevede kabul etmezler. Bunun yerine sürü davranışı 
göstererek güvenli olanın toplumun ekseriyetince kabul edilmiş olan olduğuna inanır ve sorgulamaksızın kalabalığa yönelirler. Bu, bir bakıma anlaşılırdır. Zira herkesin temel gayesi güvenlik ve ardından konfor ise; sürünün bulunduğu pozisyon ortaklaşa biçimde güvenli olduğu yahut birlikte olunduğunda güvenli olacağı düşünülen, buna inanılan pozisyondur. Böylece kalabalıklar onaylanma makamı haline gelir. Kalabalığın kabul ettiği, beğendiği normal ve doğru; reddettiği ve sevmediği anormal ve kötü olarak damgalanır. Bu nedenle toplumla ters düşmek, geleneksel yaşam içerisinde yaşam olanaklarından dışlanmak anlamına gelir. Dolayısıyla geleneksel yaşamı etkisi altında tutan inançla ters düşmek de bu noktada hayati bir yanlış haline gelir. İnancın geleneksel toplumda sorgulanması bu yüzden mümkün değildir.

Öte yandan böyle bir yapıda dayanışma kültürü egemendir ve dayanışmanın organizasyonu da bilgeliğe, tecrübeye, yüceliğe, güvene ve korkuya dayanır. Toplumsal organizasyonda akrabalık bağları, hiyerarşiler, itibar ve statüler oldukça önemlidir. Toplumsal örgütlenme dikey biçimde hiyerarşiktir; soylular, ruhbanlar, aile büyükleri ile üreteciler arasında bir buyurganlık ilişkisi bulunur. Yine güven ve korku bu yapı içerisinde toplumsal yaşamın temelidir. Özellikle de üretici sınıf içerisinde güveni bir asgari müşterek haline getiren şey ise tanrısal düzen, yasa ile ödül-ceza düzenekleridir. Yani güven esasen insana değil, tanrını//doğanın/yüce olanın kendisine; onun düzenine, yasasınadır. Zira insanı toplumsal yaşam içerisinde dizginleyen, terbiye ve islah eden odur. Onun düzeninin bekçisi, eli, gölgesi olan kişiler de yasaya uyduğu müddetçe, ona gösterilen hürmetten ve korkudan paylarına düşeni alırlar.

Bu çerçevede Doğu, refleksivitenin ve Aydınlanmanın yokluğunda bu anlayışın baskın ve yoğun bir şekilde toplumsal yaşamın her bir gözeneğine, her bir kılcalına nüfuz ettiği ve halen daha canlı tuttuğu yerdir. Doğu insanı toplumsal yaşamı mümkün kılan davranışsal ideallerin kaynağını her daim aşkın idelerle anlamlandırır. Hakkın ve adaletin gayesi dünyevi olsa da kaynağı tanrısaldır. Hem ... hem toplumu işte bu aralığa bir sıkışmadır. Dünyevi olanın acımasızlığı, kendiliğindenliği ve öyleceliği karşısında gerçeğin inkarına yönelik bir bilinç dışı tepki olarak ya kendini kandırmaya yönelik optimist bir teslimiyetçiliğe sığınır ya da sebatının karşıllğı olarak alternatif gerçeklikler yaratır. Aslında bu davranışlar pasif-agresif tutumlardır ve kaderci- 
liğin gelişmesini sağlar. Her daim haksızlıklar ya da olanaksızlıklar karşısinda yolun sonunda beklemekte olan yüce ve bilinemez bir amaca sığınır. Bu bir bakıma Freud'un temelini attığı ve Anna Freud'un geliştirdiği savunma mekanizmalarından yüceltmeye karşlık gelir. "Yüceltmenin, yani dürtü amacının daha yüksek sosyal değerler yararına yer değiştirmesinin ön koşulu, bu tür değerlerin kabul edilmesi ya da en azından bilinmesi, yani üstbenin varllğıdır" (Freud, 2011, s.43).

Üstben tanrı, ruhban ve yetkilendirilmiş (tanrının gölgesi konumundaki) yöneticidir. Bu nedenle yaşananlar ya da iktidarlar tarafından alınan kararlar tanrının iradesinin yansıması olarak görülür. Bununla birlikte dinlerin zihin haritalarına sinen ve Antik Yunan'dan günümüze kadar gelen erekselliğin ${ }^{3}$ izleri her şeyde olduğu gibi insanların yaşamında da aranır ve katlanmak için bir neden verir. Her şeyin bir nedeni vardır. Bu amaç, fanilerin kavrayışına sığmayacak denli büyüktür; ancak sebat ve teslimiyetin açacağı kapıdan geçilmesi sonrası karşılaşılacak bütünle birleşilince kavranabilir. Batı Aydınlanma deneyimi ile bu zihin atlasını aşmayı başarmış ve yaşamı sekülerleştirebilmiştir. Dünya hayatında modernizmi memnuniyetle kuşanır. Fakat Doğu, insana ve doğaya dair gerçeklikler karşısında bu kaçış mekanizmasını tam anlamıla karakterize etmiştir. Böylece kadercilik ve asketizm bir mistik bulut olarak Doğu'nun ruhu, doğu öğretileri vb. anlamlandırmalar biçiminde geniş coğrafyalarda hükmünü devam ettirir.

Buna karşın Aydınlanma sonrasının Batısı ise bir ya ... ya da medeniyeti haline gelmiştir. Uhrevi olanı dünyevi olanda yaşatmak gibi bir amacı kalmamıştır. Uhrevi olan dünyevi olanın akışı içerisinde sınırı bir zaman ve uzamda kendine yer bulabilir. Asıl olan her daim dünyevi olandır. Bu dünyanın gerçeklikleri eskinin öğretilerini ve bakış açlarını moral bir enstrümana indirgemiştir. Özellikle de Aydınlanmanın eğitim ve bilime yaptığı vurgu insanlığın inancı bir yumurta kabuğu gibi parçalayarak sınırları dışına çıkmasına, gerçek anlamda doğmasına; Platon'un mağarasını son kez ve sonsuza dek terk etmesine fırsat vermiştir. Aydınlanma sonrası artık bir ya ... ya

\footnotetext{
${ }^{3}$ Bir maddenin biçim kazanmasında son olarak bir de amaç bulunmalıdır ve işte bu amacı gösteren nedene de ereksel neden denir. Yani taş ustası mermeri bir forma sokmaya çalışırken, taş ustasıının kafasındaki amaç, mermeri bir mezar taşı hâline getirmektir. Bu amaçta, taş, bir mezarlıkta ölünün başucuna dikilecek, onunla ilgili bazı temel bilgileri kitabe gibi taşıyacaktır. Böylece dördüncü neden yani amaç ya da erek neden (causa finalis) de belirlenmiş olacaktır. Bu düşünce zinciri hayatta olan biten her şeyin de tanrının mizanseninde bir yeri ve nedeni olduğu sonucuna bağlanarak kaderciliği beslemiş; özellikle Orta Çağ'da skolastik düşüncenin kendini tahkim etmesinde etkili olmuştur.
} 
da medeniyeti olarak Batı, tercih yapma özgürlügünü eline geçirmiştir. İradesinin sadece toplumsal yaşamı değil aynı zamanda dünyayı da biçimlendirme gücünü idrak etmiştir. Bu idrak hakların ve sorumlulukların idealize edilmiş idelere atıfla anlamlandırılması ve içselleştirilmesi yerine yaşamın somut gerçekliklerinden hareket edilmesini; ahlakın, hakların, sorumlulukların ve tabii yasanın yaşamın somut ihtiyaçları ile ilişkili olarak açıklanmasını ve türetilmesini sağlamıştır.

\section{Sonuç}

Avrupa, Antik Yunandan devraldığı felsefi ve siyasal miras üzerinde biçimlenmiştir. Bu miras öylesine güçlü, farklılaştırıcı ve temellidir ki, Avrupa'yı bilinen dünyanın geri kalanından kopartmış ve zihinsel kırılma yaratarak Doğu-Batı ayrımını oluşturmuştur. Antik Yunanda başarılan şey, insanın kendi varlığını tümdengelimci bir mantıkla yaratıcı güçlere dayanarak anlamlandırmak yerine, tüm çıplaklığı, çaresizliği ve zaaflarıyla doğa yasaları çerçevesinde anlamaktır. Böylece insan ilk kez kendi varoluşunun gerçekliğiyle yüzleşmeyi başarmıştır. Bu insanın doğa üzerine, kendi üzerine düşünme deneyimini ifade eden refleksivitedir. Resleksivite o dönemin Yunanistan'ında gerekli koşullar mevcut olduğundan kurumsal bir nitelik kazanarak felsefe haline gelmiştir. Felsefe düşünen insan ve düşünen toplumun düşünme aracıdır. Kesinlikle ve kaçınılmaz biçimde döneminin bilimsel gelişmeleriyle ilintilidir. Öte yandan bu kıvılcım, Roma İmparatorluğu ve sonrasında ise Kilisenin yönetimleri altında uzun ve derin bir uykuya dalmıştır. Platon ve özellikle de Aristo felsefesinde ortaya konan unsurlar bilhassa Roma İmparatorluğu sonrası dönemde Önce İslam düşünürleri tarafından, sonra Orta Çağ karanlığının Slokastisizminin mimarları tarafından tanrının varlığını ve yaratılışçı tezleri desteklemek için kullanılmıştır. Bu süreç içerisinde Yunan Felsefesinin eşsiz mirası her ne kadar Skolastik düşünceye yamanmaya çalışılsa da özünde barındırdığı refleksivite sayesinde yeni bir dünyanın da başlangıç ateşini yakmayı başarmıştır. Önce Reform ve Rönesans ile ortaya çıkan değişme, ilerleyen dönemde Aydınlanma ile zirveye çımış, siyasal ve ekonomik alandaki gelişmelerle de birleşerek bugün adına modernizm dediğimiz yepyeni bir evrenin inşasını sağlamıştır. 
Anlaşılacağ 1 üzere modernizm Antik Yunan felsefe ve siyaset mirasının Batı'nın kendine has ekonomik ve toplumsal yapısıyla birleşmesi sonucu ortaya çıkmış; savaşlar, kıtlıklar, hastalıklar, sınıfsal mücadeleler ve Doğu'nun askeri sıkıştırmaları sonucu biçimlenmiştir. Modernizm Avrupa'nın eski döneminin tam anlamıla tepe taklak edilmesidir. Yarattı̆ı birçok kavram ve olgu onun zorlama olmaktan çok uzak, altında önemli bir miras ve birikim bulunan kaçınılmaz bir sonuç olduğuna işaret etmektedir. Dolayısıyla rahatlıkla ifade edilebilir ki, modernizm Batı uygarlığının kendi gelişim süreci içerisinde ortaya çıan doğal ve ona has bir yaratıcı anlatıdır. Buna karşın Doğu'nun kendi tarihiselliği içerisinde Batı'nınki gibi olgulara ya da durumlara rastlamak güçtür. Elbette Aristo, Machiavelli, Montesquieu ve diğer pek çok düşünürün ifade ettiği gibi bu durum coğrafya, iklim, bitki örtüsü gibi etmenlerle doğrudan ilişkilidir. Dahası bu etmenler inanç sistemleri ve toplumsal organizasyonu da belirleyerek Doğu toplumlarının yaşamına iki koldan yön vermiştir. Batı'nın Yunan mirasını geliştirmesi, bilim, teknik, mimari ve sanatta yeni bir vizyon ortaya koyması karşısında Doğu toplumları bir yanit üretememiştir. Batı (burada kast edilen Avrupa'dır), modernizmin karakteri gereği epistemeye yönlenmiş ve kendisine bilen-bilinen ikiliği, tümevarımcılık, şüphecilik, açıklama çabası, praksis, ilerlemecilik, ölçümlenebilirlik gibi ayırt edici parametreler üzerinde bir ideal tip oluşturmuştur. Bu parametreler Aydınlanma ve Pozitivizm kavramları altında toparlanmıştır. Bu gelişmeler öncesinde merkantilizm ve akabinde kapitalizmin ortaya çıkışıla Batı için dünyayı orijinal ve otantik, biz ve onlar, özne ve nesne olarak ikiye ayırmıştır. Bu andan itibaren Batı Doğu'ya modernizmin karakterinden ileri gelen bir güdüyle bilen fail olarak yaklaşmış ve onu bilinen konumunda nesneleştirmiştir. Bu andan itibaren Doğu, Batı için gerçekliğin çözümlenmesi ve açıklanmasındaki bir araştırma nesnesine dönüşmüştür. Dolayısıyla kendi içinde durağan, döngüsel bir yaşamın evi olan Doğu, birdenbire bilim ve teknikteki ilerlemelerin sonucu olan araçlarıyla kendini kuşatan dinamik ve çizgisel bir zaman algısının aceleciliği ve hoyratlı̆̆ına sahip Batı tarafından yakılıp yıkılmış, sömürgeleştirilmiş, horlanmıştır.

Doğu, sahip olduğu büyük tarihsel mirasla övünürken Batı tarafından canı yakılmış, başarısızlığa uğramış, boyunduruk altına alınmıştır. Bu durum Doğu üzerinde büyük bir travma yaratmıştır. Travma o denli büyüktür ki, Doğu buna birkaç yüzyıl boyunca yanıt dahi üretememiştir. Sonunda düştüğü durumun nedeninin Batı'da yaşanan bilimsel ve teknolojik gelişmeler 
olduğuna kanaat getirerek aynı rotayı izlemeye karar vermiştir. Doğu'nun yapması gereken basittir: Bilim, teknik, yönetim, eğitim, sanayi ve kılık-kıyafet gibi görünür farkları aynen tatbik etmek. Mademki, insan içinde yaşadığ1 koşullar tarafından biçimlendirilmektedir, o halde o koşullar değiştirilirse Doğu da tıpkı Batı gibi gelişim gösterebilir ve hak ettiği pozisyona gelebilir.

Ancak atlanan bir nokta vardır. Batı'nın kendi ontolojisi episte merkezli, şüpheci, tümevarımcı ve praksise yönelik bir ontolojidir. Bu özellikler ne Doğu toplumlarının özünde bulunmaktadır ne de yaşadıkları doğa koşulları böyle parametrelerin oluşmasına olanak sağlamıştır. Yani Doğu'nun Batı'dan transfer edeceği şeylerin toplumları kökten değiştirmesi imkansızdır. Yapılacak değişimler sadece refah üzerinde etki yaratabilir. Nitekim öyle de olmuştur. Doğu toplumları modernizmin kendileri açısından okunması imkansız bir zihin haritasını izlemek olduğunu anladıkları anda modern olmak yerine çağdaş olmaya yönlenmişlerdir. Böylece şekilci bir Batılışma, çağının en ileri medeniyeti Batı olduğu için, tüm Doğu coğrafyalarını sarmıştır. Bu aynı zamanda Batı ile rekabet de edebilecekleri bir alan yaratmış, Doğu ile Batı ikiliğini sonsuzlaştırmıştır.

Doğu, Batı'ya yetişme hevesi ve azmiyle modernizmin toplumsal yaşam, üretim-tüketim ilişkileri, hukuk ve yönetim konusundaki yeniliklerini büyük ölçüde uygulamış, Batı'nın sanayileşme rotasında onunla yarışa tutuşmuş, hatta yer yer onu geçmeye çalışmıştır. Böylece refah ile mutluluk arasında kurulan kapitalist ilişki Doğu tarafından da kabul edilmiş ve büyük bir kalkınmacılık hareketi Doğu'da yayılmıştır. Kalkınmacılık sağ politikalar ve taşra milliyetçiliğiyle de birleşerek Doğu açısından Batı ile hesaplaşmanın, ona karşı çıkmanın bir enstrümanına dönüşmüş ve fetişleşmiştir.

Doğu hiçbir zaman modern olamayacaktır. Bu anlamda modernleşme çabası boş bir çabadır. Fakat modernleşmeye gerek var mıdır? Ontolojik olarak birbirinden tamamen farklılaşmış iki dünyanın birbirine benzemeye çalışması zaten en başından anlamsızdır. Üstelik içinde bulunduğumuz dönem artık modernizmin sona erdiğinin ilanına ve post-human (insan-ötesi) olarak adlandırılan bir yeni döneme girildiğini haber vermektedir. O halde açıktır ki, önemli olan çağın mutluluk yaratıcı temel veevrensel gereksinimleri çerçevesinde toplumsal ve küresel bedenden kopmadan en iyisini aramak, en iyisini yapmaktır. Bu elbette modernizmin hükmünü yitirdiği bu dönemde daha da önemlidir. Doğu'nun ortaya koyacağı çaba ve anlayış belki gelecek dönemde iki ayrı kutbun daha da bütünleştiği bir dönem olmasını sağlayabilecektir. 


\title{
EXTENDED ABSTRACT
}

\section{Modernization Problem And Contemporation Of East From Perspective Of Enlightenment}

\author{
Ergin Ulusoy \\ Nuh Naci Yazgan University
}

The study deals with the foundations of the separation between the West and the East and the transformation of this separation into a rupture in the axis of modernism. Modernization originating from the West and spreading to the world essentially bears the traces of historical and cultural experiences of Western. Therefore, modernization has been interpreted primarily as a mental and cultural invasion in non-Western societies. A reflexive stance, a denial and rejection has emerged against this not only at the institutional level but also at the social level.

The features that distinguish the West and the East and form a dichotomy against each other arise from their approach to human, nature, existence and being. The point that makes Ancient Greece unique for the West is already related to this difference of approach. Ancient Greece succeeded in looking at man, nature and the interaction between man and nature from a materialist point of view within the framework of causality, gave place to the idea that nature should be explained before making sense, and took a revolutionary step, such as thinking about itself as a species and as an individual. In this respect, the East has given a god-centered meaning to nature within the framework of its own originality and has not given a significant place to the attempts to explain, which is independent of god, leaving aside its existence. This great leap in Ancient Greece is the reason why science, as we know it today, originated from the West.

Therefore, the study bases its main hypothesis on the claim that modernism was built on an atlas of mind based on the Ancient Greek heritage. In this context, there is a fundamental difference between West and East that causes them to break from each other.

This is the reason why the West tries to claim Ancient Greece as a return to roots, to the essence. Just as the Reformation and the Renaissance rose 
above the thoughts of Ancient Greece and tried to transcend them; Rationalism, Enlightenment and Positivism can also be regarded as the creation of a new mental universe that basically started out from Ancient Greek thought and finally succeeded in transcending it. In this context, Rationalism, Enlightenment and Positivism, which are considered as components of modernism in the study, show that while the West reforms civilization, it is now coming out of the "ontological" grip of the Middle Ages and turning towards epistemology. This is why everything modern is based on objects such as calculability, universality and reason, which are oriented towards objectification, comparison and planning.

At this point, the study argues that the modernization of the East is impossible and it grasps the subject in an epistemology-ontology duality. Modernism was born in the mental folds of the West. Modernization, as its process, can only integrate with the body that gave birth to it, without tissue rejection. Because the East has an atlas of mind separate from the mental maps of modernism, its modernization will remain essentially a compulsory "modernization" movement devoid of modernism as an ideological material. Therefore, the cultural and social difference between East and West will be more disintegrating and even ossifying this separation, rather than being unifying at the point where modernity is globalized.

In this process of rupture and solidification, the West has positioned itself as the knowing (great critic) with the Enlightenment, taking everything before itself as known. It has caused the West to marginalize others it encounters, even objectify and dictate them as the subject of their research. Thus, the East versus the West has turned into laboratory research. Everything that happens in the East has been falsified and criticized against the absolute and universal realities of the West. The East has been forced to gain meaning within a pattern set against Western modernism. It faced the consequences of this dilemma in the heaviest and wanted to develop, change, become Western and catch up with the West by reading what happened to her within the framework of the back and forth duality. In a way, he was obliged to do so. Because at the root of Western there are economic and political changes that radically change social life. At this point, the East believed that salvation could be achieved if developments in this field of science and technique could be applied. This judgment means that modernism, which was created by the West, penetrates the East. Because, wanting to develop, accepting its 
backwardness means seeing oneself through the eyes of the West, using the comparisons that it uses, means taking its right-wrong table as a basis.

Working in line with the modernization of the East that's trajectory is impossible to discuss -lig and modernization of the East never the ideological perspective not alımlan, but rather a modernization, is reviewed as a matter of applying the requirements of the age; he claims that he has finally evolved into developmentalism as an idle practice devoid of theory .

In the study, the conflict between modernism and traditionalism and the problematic relationship of the East with Western modernism are examined. In this direction, an effort has been made to make a comparative reading in which differentiation such as epistemology-ontology, induction-deduction between West and East is centered. During the preparation of the study, a literature review was made. In this sense, the study follows an Enlightenment, positivist theme and moves through a Western-style modernism reading. However, care was taken to stay within an objective, scientific and logical framework and to avoid orientalist prejudices.

The study aims to present a logical, objective analysis based on cause-effect relationships on a ground where concepts such as post-modernity and post-truth erode scientificity; it is aimed to take a scientific stance to the relativity hegemony in social sciences.

\section{Kaynakça / References}

Adorno, T. W. ve Horkheimer, M. (2010).Aydınlanmannn diyalektiği.İstanbul:Kabalcı Yayinevi.

Bacon, F. (1999). Nơum organum. S. Ö. Akkaş (Çev.), Ankara: Doruk Yayıncllk (Birinci Basım). $22-27$.

Batu, M. ve Tos, O. (2017). Tüketim kültürü odağında modernizm ve postmodernizmin karşlaş̧ırılması. Gümüşhane Üniversitesi İletişim Fakültesi Elektronik Dergisi, 5(2), 991-1023.

Berger, P. L.,Berger, B. ve Kellner, H. (2000).Modernleşme ve bilinç (Cevdet Cerit, Çev.). İstanbul: Pinar Yayınları.

Cevizci, A. (1999).Felsefe sözlüğ̈̈. İstanbul: Paradigma Yayınları.

Cidade, E. C. vd. (2016). Poverty and fatalism: Impacts on the community dynamics and on hope in Brazilian residents. Journal of prevention \& intervention in the community, 44(1), 51-62. 
Duran, R. (2008). Postmodernizm bir düşünce okulu mudur?.Hece Dergisi, 16, 138-139140-142-152.

Descartes, R. (1989). Akhn idaresi için kurallar.(M. Karasan, Çev.). İstanbul: MEB Basımevi.

Descartes, R. (2015).Yöntem üzerine konuşma.(A. Timuçin ve Y. Timuçin, Çev.).İstanbul: Bulut Yaynnları.

Eisenstadt, S. N. (2007). Modernleşme, başkaldırı ve değişim. (U. Coşkun, Çev.). Ankara: Doğu Batı Yayınları.

Er, K. (2014). Üretim ilişkileri temelinde modernizm ve postmodernizmin azgelişmiş ülkeler üzerine etkileri. Dokuz Eylül Üniversitesi Sosyal Bilimler Enstitüsü Dergisi, $16,3,413-453$.

Freud, A. (2011). Ben ve savunma mekanizmaları, (Y. Erim, Çev.). İstanbul: Metis Kitap Furat, A. H. (2010, Aralık 15). Modernleşme mi batılılaşma mı çağdaşlaşma mı?. Haber Sol. 01 Mart 2020 tarihinde, https://haber.sol.org.tr/serbest-kursu/modernlesme-mi-batililasma-mi-cagdaslasma-mi-ali-haydar-firat-haberi-36959 adresinden erişildi.

Göle, N. (2004). Batt-dışı modernlik kavramı üzerine. (Der.) T.Bora ve M. Gültekingil Türkiye'de Siyasi Düşünce: Modernleşme ve Batıcllk içinde. C.3. İstanbul: İletişim Yayınları.

Gümüs,s, S. (2015) Modernizmin dünü ve yarnı: Edebiyatın dünü ve yarmı. 3. Bsm. İstanbul: Can Yayınları. 02 Şubat 2020 tarihinde ailehttps:/play.google.com/books/reader?id=EDKADQAAQBAJ\&hl=tr adresinden erişildi.

İter, Tuğrul (2006) Modernizm, postmodernizm, postkolonyalizm: Ben-öteki ilişkileri ve etnosantrizm. Küresel Illetişim Dergisi, 1, 1-14

İmamoğlu, T. (2013). Modern batı düşüncesinin felsefi temelleri. İstanbul: İz Yayınları.

İmamoğlu, T. (2017). Modernizm üzerine eleştirel bir değerlendirme. Kafkas Üniversitesi İlahiyat Fakültesi Dergisi, 4(8), 1-10. DOI: 10.17050/kafkasilahiyat.334058

Jacques E.(1998). Sözün düşüşü̈.(H. Arslan, Çev.).Istanbul: Paradigma Yayınları.

Kirman, M. A. (2004).Din sosyolojisi terimleri sözlü̈̆̈̈. İstanbul: Rağbet Yayınları.

Küçükkaya, T. (2018). XX. yüzyll şüpheciliği (post-modernizm) ve etik problemler. International Journal Of Religion \& Philosophical Research/Uluslararast Din \& Felsefe Araştırmalan Dergisi 1(1). 16 Ocak 2020 tarihinde http://dfa.dfd.org.tr/dergi/xxyuzyil-supheciligi-ve-etik-problemler--talha-kucukkaya_8_tr.pdf adresinden erişildi.

Kuşat, A. (2000). Psikolojik bir olgu olarak kendini aldatma ve dini inançla ilişkisi. Dini Araştırmalar, 3(8), 97-116. 
Levinas, E. (1969). Totality and infinity: An essay on exteriority. (A. Lngis, Çev.). Pittsburgh: Duquesne University Press.

Maher, M. (1909). Fatalism. In The Catholic Encyclopedia. New York: Robert Appleton Company. 21 Kasim 2019 tarihinde http://www.newadvent.org/cathen/05791a.htm adresinden alind.

Marshall, B. (2006). Katı olan her şey buharlaşıyor. (Ü. Altuğ, B. Peker, Çev.).̇ंstanbul: İletişim Yayınları.

Oktay, C. (2010).Siyaset bilimi incelemeleri, 5. bsm. İstanbul: Alfa Yayınları.

Serdaroğlu, U. (2010). Feminist iktisat bilimi sorguluyor. Iktisat ve Toplumsal Cinsiyetiçinde. (U. Serdaroğlu vd., Der.) Ankara: Elif Yayınevi.

Shayegan, D. (1991). Yaralı bilinç geleneksel toplumlarda kültürrel şizofreni. birinci Baskı.(H. Bayrı, Çev.) İstanbul: Metis Yayınları.

Şimşek, F. (2017). Modernizm ve gelenek arasında bir ütopya: Maskeve ruh. Selçuk Üniversitesi Edebiyat Fakültesi Dergisi (SEFAD), 38. 161-178.

Touraine, A. (1995). Modernliğin eleştirisi.(H. Tufan, Çev.). İstanbul: Yapı Kredi Yayınları.

Yılmaz, H. (2005). Gelenek, gelenekçilik, gelenekselcilik.Muhafazakâr Düşünce Dergisi, 3. $39-53$.

\section{Kaynakça Bilgisi / Citation Information}

Ulusoy, E. (2021). Aydınlanma perspektifinden doğu'nun modernleşme sorunu ve çağdaşlaşma. OPUS-Uluslararası Toplum Araştırmaları Dergisi, 17(36), 3089-3119. DOI: 10.26466/opus.765187 